\title{
FIXED CAPITAL INVESTMENT IN Q1 2016
}

\author{
O. Izryadnova
}

In January-March 2016, fixed capital investment stood at 95.2\% in real terms, including in the segment of large and medium enterprises to the tune of 98.5\% against the corresponding period of the previous year. The share of own capital posted an upward trend in the structure of sources, which are financing fixed capital investments. Investments in the mining and quarrying sector went up by $7.1 \%$ and positively affected the investment movements of large enterprises in Q1 2016.

Contraction of investment in manufacturing by 5.8\% in Q1 2016 against the corresponding period of the previous year was accompanied by an unprecedented activity in the machine-building complex.

The situation in the investment sector of the economy this year is determined by a fall of fixed capital investment in the course of the consecutive twenty quarters. In Q1 2016, fixed capital investment amounted to 95.2\% and the scope works completed in the construction sector came to $98.5 \%$ on the corresponding indicators of 2015. The share of fixed capital investment in Q1 2016 stood at $11.6 \%$ of GDP, being 0.8 p.p. above the indicator of the corresponding period of the previous year. It should be noted that although forecasts of the domestic investment demand are not very optimistic amid current dynamics of financial and economic activity, the businesses are gradually adapting to the new conditions. Slackening of both contraction of investment and construction activity scale, most likely, is due to a gradual transition from the measures of anti-crisis regulation to the formation of programs aimed at sustainable development.

Fixed capital investment movements are differentiated across economic agents. In Q1 2016, in the segment of large and medium enterprises fixed capital investment came to $98.5 \%$ amid strong downward trend in construction and investment activity seen in the segment of medium and small enterprises.

In Q1 2016, the structure of fixed capital investment saw an increase in volumes and share of investment earmarked for machinery and equipment amid a contraction of the share of investment seen in residential property construction. In 2016, reallocation of the investment funds across the types of capital stock was under the influence of change of price structure of the investment goods and services. When the producers of construction materials reduced their prices by $1.4 \%$ in March 2016 against December

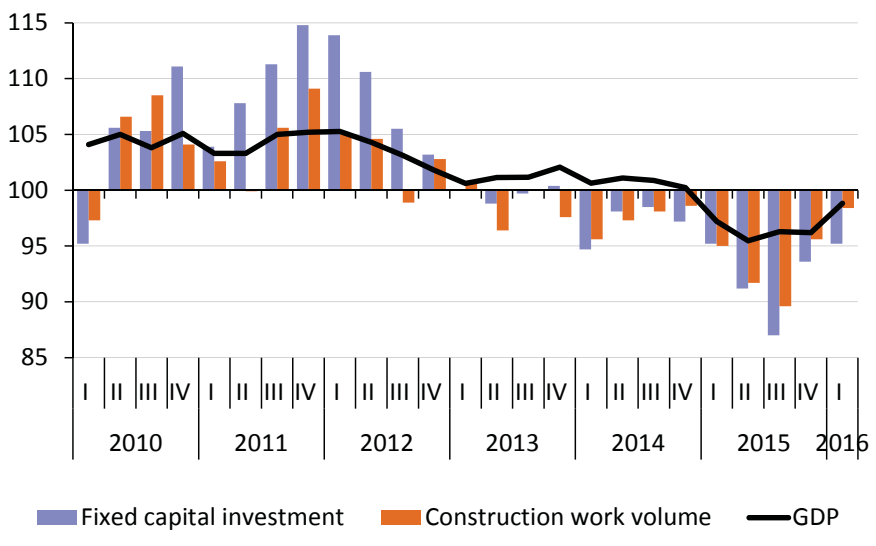

Fig. 1. Dynamics of fixed capital investment in 2011-2016, $\%$ to the corresponding quarter of the previous year 
Table 1

DYNAMICS AND STRUCTURE OF FIXED CAPITAL INVESTMENT AS BROKEN BY TYPE OF CAPITAL STOCK IN Q1 2012-2016 (LESS SMALL BUSINESS AND INFORMAL ACTIVITY PARAMETERS), \% TO TOTAL

\begin{tabular}{|c|c|c|c|c|c|c|c|c|c|c|}
\hline & \multicolumn{5}{|c|}{$\mathrm{Rb}$ bn } & \multicolumn{5}{|c|}{$\%$ to total } \\
\hline & 2012 & 2013 & 2014 & 2015 & 2016 & 2012 & 2013 & 2014 & 2015 & 2016 \\
\hline $\begin{array}{l}\text { Fixed capital } \\
\text { investment }\end{array}$ & 1211.0 & 1310.2 & 1429.7 & 1516.7 & 1609.7 & 100 & 100 & 100 & 100 & 100 \\
\hline \multicolumn{11}{|l|}{ Of which: } \\
\hline Residential housing & 48.4 & 63.9 & 81.7 & 82.5 & 78.9 & 4.0 & 4.9 & 5.7 & 5.4 & 4.9 \\
\hline $\begin{array}{l}\text { Buildings (other } \\
\text { than residential } \\
\text { buildings) and } \\
\text { facilities }\end{array}$ & 604.6 & 609.4 & 710.6 & 706.0 & 758.7 & 49.9 & 46.5 & 49.7 & 46.6 & 47.1 \\
\hline $\begin{array}{l}\text { Machines, } \\
\text { equipment, and } \\
\text { means of transport }\end{array}$ & 441.1 & 506.5 & 481.7 & 528.4 & 564.6 & 36.4 & 38.6 & 33.7 & 34.8 & 35.1 \\
\hline Other & 116.9 & 130.4 & 155.7 & 199.8 & 207.5 & 9.7 & 10.0 & 10.9 & 13.2 & 12.9 \\
\hline
\end{tabular}

Source: Rosstat.

2015 , price indices on purchasing capital machinery and equipment went up by $3.6 \%$.

In 2012-2015, investment in the residential housing construction saw the share and amount of population's funds grow in the cost sharing residential housing construction amid growing reduction of funds invested by organizations. In Q1 2016, the funds received for the cost sharing construction, for the first time in recent five years, fell by $\mathrm{Rb} 2.4 \mathrm{bn}$. Low backlogs in the construction sector registered in 2015 determined that the organizations of all forms of ownership commissioned in Q1 $201615.6 \mathrm{mn}$ sq. m of the total living space, which was by $16.3 \%$ less than during the corresponding period of the previous year. Individual developers commissioned $6.3 \mathrm{mn}$ sq. m (40.5\% of the overall volume of residential housing commissioned in Q1 2016) with $9.4 \mathrm{mn}$ sq. $\mathrm{m}$ of the total living space $(51.0 \%)$ constructed a year earlier. While analyzing this indicator, one should bear in mind that in Q1 2016 a sharp slowdown of investment in the residential housing construction was registered, which can negatively affect movements of housing commissioning through the end of this year.

The population's investment activity has sharply dipped: the funds of the population earmarked for the cost sharing construction shrank by $\mathrm{Rb}$ 3.3bn compared to Q1 2015. To note, amid the general downward trend in the population's income and contraction of savings ratio, Q1 2016 registered growth of housing loans origination in comparison with Q1 2015 when there was an absolute reduction both of housing and mortgage loans origination in comparison with the previous year. Increased credit activity of the population was accompanied by the growth of past due debt on housing loans, which as of 1 April 2016 went up to Rb $74.8 \mathrm{bn}$ (1.8\% of the total debt on housing loans) against $\mathrm{Rb} 54.0 \mathrm{bn}(1.5 \%)$ a year earlier.

Increased share in the construction of non-residential buildings in 2016 was determined by growth of construction work and commissioning of building of industrial and agricultural purpose amid reduction of construction of administrative and commercial buildings and social sphere buildings. 


\section{CHANGE IN COMMISSIONING OF BUILDINGS ALONG TYPES IN Q1 2016} COMPARED TO Q1 2015

\begin{tabular}{|l|c|c|c|}
\hline $\begin{array}{c}\text { Number } \\
\text { of buildings, units }\end{array}$ & $\begin{array}{c}\text { Gross building } \\
\text { volume, } \\
\text { thousand } \mathrm{m}^{3}\end{array}$ & $\begin{array}{c}\text { Total floorage } \\
\text { of buildings, } \\
\text { thousand } \mathrm{m}^{2}\end{array}$ \\
\hline $\begin{array}{l}\text { Buildings com- } \\
\text { missioned }\end{array}$ & -22349 & -15126 & -4825.1 \\
\hline $\begin{array}{l}\text { Residential } \\
\text { Non-residential, }\end{array}$ & -22053 & -15637.1 & -4965.8 \\
\hline including: & -296 & 511.1 & 140.7 \\
\hline Industrial & 53 & & 126.5 \\
\hline Agricultural & 76 & 3545.5 & 684.9 \\
\hline Commercial & -192 & -1833.9 & -241.4 \\
\hline Administrative & -27 & -51.6 & -1 \\
\hline Educational & -18 & -460.9 & -81.6 \\
\hline Health care & -51 & -296.2 & -69.1 \\
\hline Other & -137 & -1730 & -277.6 \\
\hline
\end{tabular}

Source: Rosstat.

Increased commissioning of industrial buildings determines a change in the technological structure of investments and affects the dynamics of costs on machinery and equipment. However, Comparison of the dynamics of the domestic equipment output, imports of capital goods and fixed capital investment demonstrate that in the existing dynamics of machine building complex operation and in the wake of the sanctions on imports of certain types of machinery and equipment the balance of technological structure of investment get broken. In Q1 2016, slackening of the investment slump was supported by the growth of domestic output of machinery and equipment and changes in the imports pattern in favor of increased share of investment goods up to $22.6 \%$ ( +1 p.p. against the indicator of the previous year). However, taking into account dynamics of these indices of the previous year, this barely affected the current situation.

The use of own funds (capital) determined the financing of investments. In Q1 2016, the share of investments at the expense of the enterprises' own funds peaked over the twenty-year period and came to $59.2 \%$ of the total volume of fixed capital investment. In Q1 2016, the rate of return in the economy as a whole declined by 2.1 p.p. against the corresponding period of the previous year. In the context of existing dynamics of financial and economic activity, accumulated funds on deposit accounts and high interest rates on loans, enterprises in order to optimize costs preferred to use their own funds.

In Q1 2016, borrowed funds from the banks and earmarked for fixed capital investment shrank by $\mathrm{Rb}$

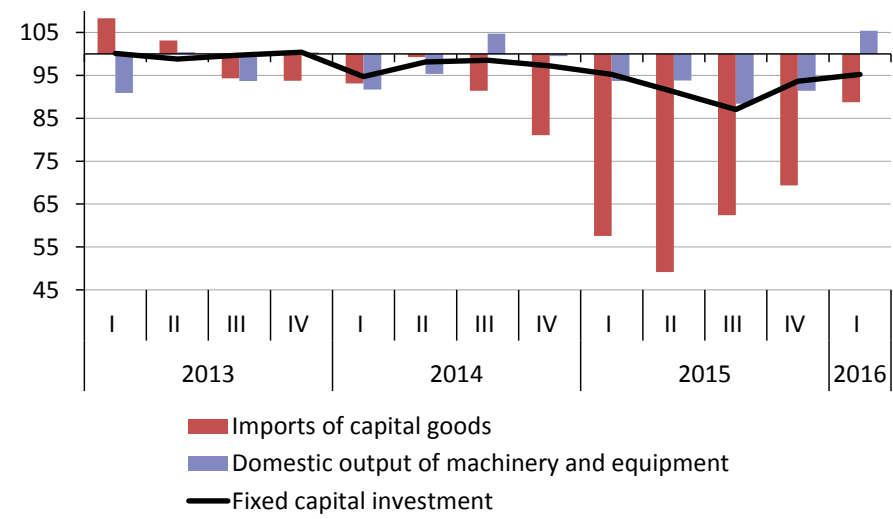

Source: Rosstat.

Fig. 2. Dynamics of fixed capital investment, imports of capital goods and domestic output of machinery and equipment (\% to the previous year) 
DYNAMICS AND STRUCTURE OF FIXED CAPITAL INVESTMENT BY SOURCE OF FINANCING IN Q1 2016, \% TO TOTAL (LESS SMALL BUSINESSES AND PARAMETERS OF INFORMAL ACTIVITY)

\begin{tabular}{|c|c|c|c|c|c|c|c|c|c|c|}
\hline & \multicolumn{5}{|c|}{$\mathrm{Rb}$ bn } & \multicolumn{5}{|c|}{$\%$ to total } \\
\hline & 2012 & 2013 & 2014 & 2015 & 2016 & 2012 & 2013 & 2014 & 2015 & 2016 \\
\hline Fixed capital investment & 1211.0 & 1310.2 & 1429.7 & 1516.7 & 1609.7 & 100 & 100 & 100 & 100 & 100 \\
\hline $\begin{array}{l}\text { Including by sources of } \\
\text { funding: (Capital) own funds }\end{array}$ & 613.3 & 693.9 & 776.5 & 891.2 & 952.8 & 50.6 & 53.0 & 54.3 & 58.8 & 59.2 \\
\hline Borrowed funds & 571.8 & 583.8 & 653.2 & 625.5 & 656.9 & 47.2 & 44.6 & 45.7 & 41.2 & 40.8 \\
\hline including: Bank loans & 97.6 & 130.3 & 140.5 & 142.6 & 126.5 & 8.1 & 9.9 & 9.8 & 9.4 & 7.9 \\
\hline $\begin{array}{l}\text { Including credits from } \\
\text { foreign banks }\end{array}$ & 23.2 & 15.9 & 18.2 & 31.9 & 17.7 & 1.9 & 1.2 & 1.3 & 2.1 & 1.1 \\
\hline Credits from Russian banks & 74.4 & 114.4 & 122.3 & 110.7 & 108.8 & 9.2 & 8.7 & 8.5 & 7.3 & 6.8 \\
\hline $\begin{array}{l}\text { Borrowed from other } \\
\text { organisations }\end{array}$ & 64.4 & 94 & 87.5 & 84.6 & 161.3 & 5.3 & 7.2 & 6.1 & 5.6 & 10.0 \\
\hline Foreign investments & $\mathrm{n} / \mathrm{a}$ & $\mathrm{n} / \mathrm{a}$ & 9.4 & 9.0 & 14.9 & 3.3 & 2.8 & 0.7 & 0.6 & 0.9 \\
\hline Budgetary funds & 133.4 & 148.4 & 137.5 & 156.7 & 145.0 & 11.0 & 11.3 & 9.6 & 10.3 & 9.0 \\
\hline $\begin{array}{l}\text { Including from } \\
\text { federal budget }\end{array}$ & 57.0 & 70.4 & 58.6 & 79.3 & 68.7 & 4.7 & 5.4 & 4.1 & 5.2 & 4.3 \\
\hline $\begin{array}{l}\text { Funds from budgets of } \\
\text { subjects of the Federation }\end{array}$ & 67.8 & 67.6 & 67.2 & 67.0 & 66.4 & 5.6 & 5.2 & 4.7 & 4.4 & 4.1 \\
\hline From local budgets & 8.6 & 10.4 & 11.7 & 10.4 & 9.9 & 0.7 & 0.7 & 0.8 & 0.7 & 0.6 \\
\hline $\begin{array}{l}\text { Funds of organizations and } \\
\text { population borrowed for } \\
\text { shared-own construction }\end{array}$ & 2.9 & 6.1 & 2.7 & 2.8 & 3.7 & 9.2 & 0.5 & 0.2 & 0.2 & 0.2 \\
\hline $\begin{array}{l}\text { Funds of organizations and } \\
\text { population borrowed for } \\
\text { cost sharing construction }\end{array}$ & 25.9 & 32.5 & 43.1 & 46.7 & 44.3 & 2.1 & 2.5 & 3.0 & 3.1 & 2.8 \\
\hline $\begin{array}{l}\text { Including funds of } \\
\text { population }\end{array}$ & 16.6 & 25.4 & 35.1 & 37.6 & 34.3 & 1.4 & 1.9 & 2.5 & 2.5 & 2.1 \\
\hline Other & 273.5 & 204.9 & 232.5 & 182.2 & 161.2 & 22.6 & 15.6 & 16.3 & 12.0 & 10.0 \\
\hline
\end{tabular}

Source: Rosstat.

$16.1 \mathrm{bn}$. At the same time, the major part ( $\mathrm{Rb} 14.2 \mathrm{bn}$ ) is due to a reduction of loans obtained from foreign banks on the back of the sanctions imposed on obtaining loans on the international financial markets. Predominance of businesses controlled by the state as well as the low level of Russian corporate governance negatively affect the influx of foreign investors to the country.

The role of the budget funds was changing in the structure of the borrowed funds earmarked for funding capital investment. In Q1 2016, fixed capital investments to the tune of $\mathrm{Rb} 145.0 \mathrm{bn}$ (9.0\% of the total volume of investments in the economy) were assigned from the budget funds. Compared to Q1 2015, the scale of investment funding from the federal budget contracted by $\mathrm{Rb} 11.7 \mathrm{bn}$ including by $\mathrm{Rb} 10.6 \mathrm{bn}$ from the federal budget funds.

According to the federal target investment program, the budget envisaged assignments to the tune of $\mathrm{Rb} 729.5$ bn for the implementation of investments and subsidies in the state facilities. During January-April 2016 the federal budget spent $\mathrm{Rb} 170.7 \mathrm{bn}$ on investments (27.8\% of the envisaged volume of the federal budget funds) and from the funds of the subjects of the Russian Federation $\mathrm{Rb} 4.1 \mathrm{bn}$ (36.7\% of the total volume of funds of the subjects of the Russian Federation). In January-April of the current year, all sources of financing disbursed investment to the tune of $\mathrm{Rb} 45.5 \mathrm{bn}$ or $7.3 \%$ of the envisaged for the year volume of funds. 
Slackening of the investment activity posted by large holdings, JSC and financial-industrial groups with the state participation in the course of 2012-2016 is telling highly negatively on the formation of the gen fixed assets. The share of investment disbursed from other sources of funding, the dominant share of which falls on the institutional investors with state participation, contracted by 2 p.p. against Q1 2015 and by 12.6 p.p. against Q1 2012. In the context of existing interest rates, large enterprises exceptionally reservedly treat the idea of widening the scope of the investment activity and stick to savings model. Although, it should be noted, that at the turn of 2016 deposits of the businesses grew with a slower pace against the demand on credit resources.

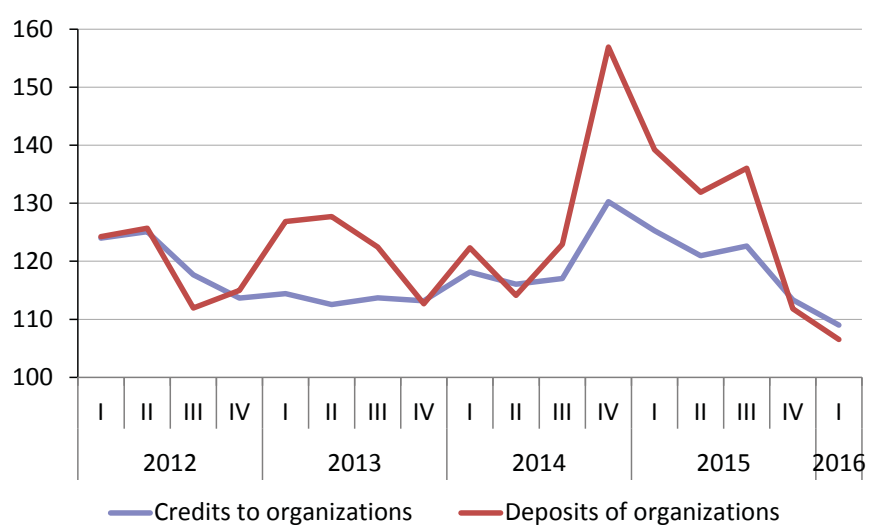

Sources: Rosstat, CBR.

Fig. 3. Movements of loans extended to organizations and borrowed deposits of organizations in 2012-2016, as \% to the corresponding quarter of the previous year

Table 4

INVESTMENT IN FIXED CAPITAL (WITHOUT SMALL BUSINESSES AND INVESTMENT VOLUME NOT OBSERVED BY DIRECT STATISTICAL METHODS) IN Q1 2012-2016

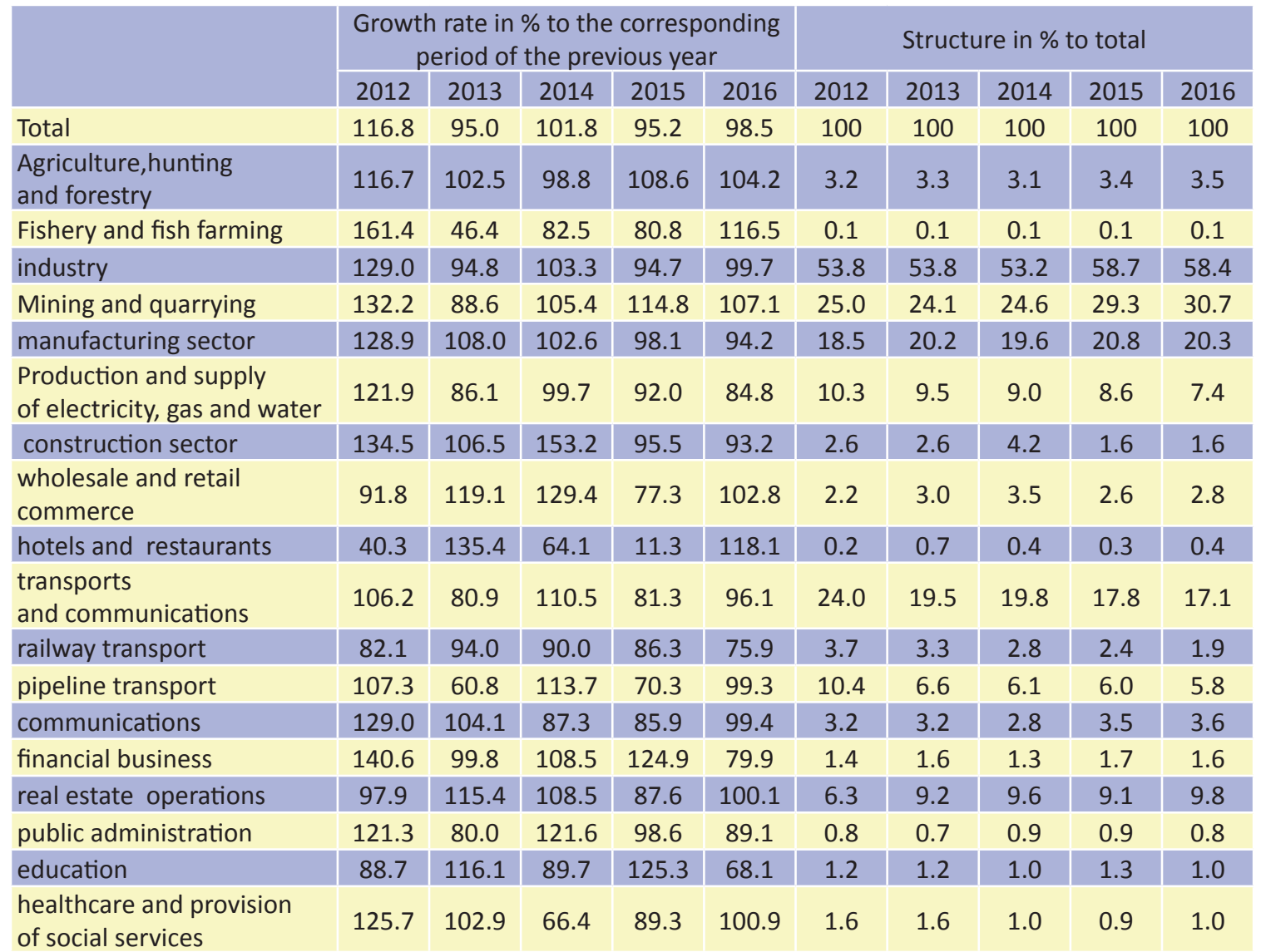

Source: Rosstat. 
During 2013-2016, the structure of investment in fixed assets across types of economic activity saw rather significant changes.

The feature of Q1 2016 was growing share of investment in fixed assets in industry in comparison with the corresponding period of the previous years. At the same time, in Q1 2016, speed up in growth of investment in mining and quarrying by $7.1 \%$ against Q1 2015 was accompanied by a contraction of capital investment in manufacturing sector by $5.8 \%$ and in production and distribution of electricity, gas and water by $15.2 \%$. At end-2016 Q1, investment in industry stood at $99.7 \%$ on the indicator of the previous year.

Structural changes in the manufacturing sector were determined by deepening decline of investment in fixed capital of machine-building complex by $25.4 \%$ in comparison with Q1 2015, in production of coke and petroleum products - by $29.1 \%$ and in the consumer complex - by $10.3 \%$. As a result, the share of investment in the machine-building complex in the overall volume of investment in the economy fell to 3.3\% with 4.4\% in Q1 2015.

Features of the changes in the structure of investment across types of activity in Q1 2016 were determined by growth of investment in chemicaltimber complex by $4.3 \%$ and in metallurgical complex by $52.5 \%$ against Q1 2015.

According to forecast of socio-economic development of the Russian Federation, projected volume of investment is estimated in the range of $96.9 \%$ (base scenario) to $90.6 \%$ (conservative scenario) compared to the previous year. The rating of challenges for the Russian investment market depends on the geopolitical situation, consistency of measures of state regulation, character of changes in spending and behavior of consumers. 